\title{
Prospects for Attracting Financial Resources in International Markets by the Republic of Belarus
}

\author{
M. P. Samokhovets ${ }^{a}$ and N. I. Kravtsova ${ }^{b}$ \\ a Poles'e State University, ul. Dneprovskoi Flotilii 23, Pinsk, 225710 Republic of Belarus \\ ${ }^{b}$ St. Petersburg State University, St. Petersburg, Russia \\ Received August 21, 2013
}

\begin{abstract}
The article evaluates the potentialities of the Republic of Belarus to attract financial resources in international markets as a relatively new and promising form of government borrowings. At the same time, a special consideration is given to the peculiarities and the attractiveness of placement of sovereign bonds in the stock market of the Russian Federation.
\end{abstract}

DOI: $10.1134 / \mathrm{S} 1075700714030095$

The placement of sovereign bonds is a relatively new tool of borrowing for the Republic of Belarus (RB), along with traditionally attracted loans from international credit and financial institutions and governments of foreign states, under the objective necessity to attract additional funds for noninflationary financing of the budget deficit and the maintenance of the balance of paymentss. Thus, in the structure of the RB external debt, the largest share belongs to credits and loans and amounts to $57.5 \%$ [1]; only $6.2 \%$ falls to the share of debt securities.

At the same time, during the last 12 years, the external debt of RB state administration bodies (100\% long term) has increased in nominal terms by more than 22 times and, in 2012, amounted to $22.6 \%$ of GDP (Table 1). A share of the external debt of RB state administration bodies in the RB gross external debt is $36.3 \%$; and the costs for servicing of external debt of RB state administration bodies, $3.3 \%$ of the national budget revenues.

On the background of existing potential of the use of government securities as an instrument of government borrowings and taking into account the increase in the external debt of RB state administration bodies over time there is a need to expand the practice of placing of RB sovereign bonds, with due account for their relative attractiveness (Table 2).

Note that the RB market of government securities is regulated by manifold resolutions of the RB Council of Ministers and the RB Ministry of Finance [2], but is not subject to the Law of the Republic of Belarus of March 12, 1992 No. 1512-XII On Securities and Stock Exchanges that determines a uniform procedure for the issuance and circulation of securities.

The issuance of government securities in the Republic of Belarus in the domestic market has been carried out since 1994 through auctions and, in certain

Table 1. Gross external debt of the Republic of Belarus (as of January 1)

\begin{tabular}{|c|c|c|c|c|}
\hline Figure & 2000 & 2010 & 2011 & 2012 \\
\hline \multicolumn{5}{|l|}{ Absolute figures } \\
\hline $\begin{array}{l}\text { External debt of state administration bodies state admin- } \\
\text { istration bodies, bln U.S. dollars }\end{array}$ & 554.3 & 8363.0 & 10057.9 & 12351.0 \\
\hline $\begin{array}{l}\text { Servicing of external debt of state administration bodies } \\
\text { state administration bodies, bln U.S. dollars }\end{array}$ & 127.8 & 288.7 & 762.1 & 552.1 \\
\hline \multicolumn{5}{|l|}{ Among them: } \\
\hline Principal payments & 105.6 & 139.4 & 547.2 & 169.0 \\
\hline Interest payments & 22.2 & 149.3 & 214.9 & 383.1 \\
\hline \multicolumn{5}{|l|}{ Relative figures } \\
\hline $\begin{array}{l}\text { External debt of state administration bodies state admin- } \\
\text { istration bodies, GPD, } \%\end{array}$ & 4.7 & 17.0 & 18.3 & 22.6 \\
\hline
\end{tabular}

Source: the authors' calculations on the base of the official data of the National Bank of the Republic of Belarus. 
Table 2. Assessment of attractiveness of sovereign bonds as a form of RB fundraising

\begin{tabular}{|c|c|}
\hline Advantages & Disadvantages \\
\hline $\begin{array}{l}\text { 1. Attraction of additional resources in foreign currency for } \\
\text { the financing of both current and investment programs }\end{array}$ & $\begin{array}{l}\text { 1. Relatively high interest rates (in comparison with the loans of } \\
\text { the EC countries, the IMF, etc.) }\end{array}$ \\
\hline $\begin{array}{l}\text { 2. Large volume of financing that can be attracted coinci- } \\
\text { dently }\end{array}$ & $\begin{array}{l}\text { 2. Heavy expenditures for servicing of the process of placement of } \\
\text { government bonds, the main part of which falls to commission to } \\
\text { professional participants of the securities market }\end{array}$ \\
\hline $\begin{array}{l}\text { 3. Enhancement of investment attractiveness, reputation } \\
\text { making in world financial markets }\end{array}$ & $\begin{array}{l}\text { 3. RB securities market legislation does not conform to interna- } \\
\text { tional requirements in full measure }\end{array}$ \\
\hline 4. Diversification of debt portfolio & \\
\hline $\begin{array}{l}\text { 5. Exception of dependence on one state-creditor and neces- } \\
\text { sity to fulfill binding obligations though the credit program }\end{array}$ & \\
\hline
\end{tabular}

Source: the authors' own work.

Table 3. Conditions of placement of RB government bonds on international financial markets

\begin{tabular}{|c|c|c|c|}
\hline Placement & Worth & Coupon rate, $\%$ & Maturity \\
\hline Luxembourg Stock Exchange, bln U.S. dollars. & & & \\
\hline August 2010 & 600 & 8.75 & August 3, 2015 \\
\hline Additional placement, August 2010 & 400 & 8.251 & August 3, 2015 \\
\hline January 2011 & 800 & 8.95 & January 26, 2018 \\
\hline $\begin{array}{l}\text { Moscow Interbank Currency Exchange, December } \\
\text { 2010, bln Russian Rubles }\end{array}$ & 7 & 8.7 & December 20, 2012 \\
\hline
\end{tabular}

Source: the official site of the RB Ministry of Finance's data.

periods (2009-2010), by direct sale to the National Bank of the Republic of Belarus within the framework of restructuring of debt of the RB Government under previous credits. Activization of $\mathrm{RB}$ activities on the issue of sovereign bonds in external markets has been noted since 2010 , when a number of following normative legal acts were adopted that regulate the issuance of RB government bonds for the purposes of the attraction of foreign investments in the economy, including the following:

The Decree of the RB President of May 13, 2010 No. 245 On the Issue of Government Bonds of the Republic of Belarus and the Resolution of the RB Council of Ministers of October 22, 2010 No. 1542 On the Issue of Long-Term Bonds;

The Decree of the RB President of October 9, 2010 No. 527 On the Organization of Issue of Government Bonds of the Republic of Belarus and the Resolution of the RB Council of Ministers of October 22, 2010 No. 1543

On some measures for the Implementation of the Decree of the President of the Republic of Belarus of October 9, 2010 No. 527.

In accordance with Decree No. 245, the Council of Ministers in 2010-2011 gained the right to issue government bonds worth up to 2 bln U.S. dollars with a maturity of at least 5 years and the placing outside the territory of the Republic of Belarus, and Decree No. 527 gave the right to issue government bonds worth up to 15 bln Russian rubles with a maturity up to 5 years, and the placing on the territory of the Russian Federation (in accordance with the Agreement on the provision of services for the organization of placement of government bonds of the Republic of Belarus denominated in the currency of the Russian Federation and emitted in the Russian Federation of December 23, 2009).

This, in August 2010, the debut issuance of RB Eurobonds (with additional placement) on the Luxembourg Stock Exchange worth 1 bln U.S. dollars took place, followed by the next issue in January 2011 worth 0.8 bln U.S. dollars. The placement of RB sovereign bonds in the RF financial market occurred in December 2010 on the Moscow Interbank Currency Exchange worth 7 bln Russian rubles [3].

Conditions of placing RB sovereign bonds in 2010-2011 (in 2012-2013 the issue was not carried out) are shown in Table 3.

The procedure of placing sovereign bonds in the international financial markets is traditional, includes a wide range of participants, and involves the following stages [4]:

- deciding the procedure for issuance of securities and determining the main characteristics of the future 
loan, e.g., the issuing volume, the coupon rate, the stock exchange where the placement will be carried out, the underwriter ${ }^{1}$ of the placement, and participants of banking syndicate;

- approving the decision to issue securities, opening the placement, and registering and placing the securities;

—reporting the results of issuing the securities.

The procedure of placing sovereign bonds in the international financial markets is traditional, includes a wide range of participants, and involves several stages [4].

The first stage is the most important. As the placement success depends in particular on how correct the issuance characteristics are. At the attraction of funds on the stock market an issuer is interested in placing of the whole issue of securities at the lowest interest rate. However, if investors assess the credit risk of the issuer higher than the proposed rates, there is a risk of incomplete placement. The selection of an underwriter and the formation of a banking syndicate are also key factors. The bank underwriter helps the issuer determine the main parameters of the issue and accepts (partially or fully) the risk of the placement, providing the issuer the attraction of funds in full. In order to enter the international stock market, the issuer must obtain the credit rating from leading international rating agencies that will enable the investors to assess the risks and the issuer's solvency and the issuer to attract debt funds at the relevant interest rate. It is important to correctly select the stock exchange where the placement of securities will occur. As a rule, stock markets of the world trade partner countries permit one to issue government bonds at lower rates. An additional factor that influences the success of the placement of securities is the situation on the global financial market. An unfavorable situation with debt obligations of any country may provoke more conservative behavior of investors that may begin to withdraw their capitals from the securities of all developing countries.

At the second stage, the role of underwriters is significant; they either repurchase the issuance of securities in full from the issuer, then place it among investors, thereby providing the issuer the attraction of 1 funds in full, or repurchase the unplaced part of securities, only partially accepting the risk.

The third stage consists of disclosing data on the issuance results and depends on the legal peculiarities of a given country. However, as a rule, this procedure contains standard terms and conditions.

\footnotetext{
${ }^{1}$ An underwriter is an investment bank (investment company) that controls the process of issuing securities and rendering intermediary services to the issuer. An underwriter can in whole or in part provide the issue of securities by means of full repurchase of the issuance from an issuer for further sale or by virtue

1 of guaranteeing of the sale of an unplaced part of the issuance
}

In the course of implementation in 2008, the Russian government set the task of creating an international financial center in Moscow, as well as a number of projects, including infrastructure, legislative, and investment projects. One of the main fields of work is the attraction of foreign issuers on the Russian stock market. Although there are no formal bans on foreign issuers entering the Russian stock market (it is necessary to have a memorandum of understanding between regulatory bodies on financial markets of the issuer and Russian regulatory bodies on financial markets), the actual number of these emissions is small.

The Republic of Belarus was the first foreign issuer in the Russian securities market. It was a milestone event for both the Russian market and the issuer. The issue of RB sovereign bonds has been prepared for several years and several times has been postponed due to unfavorable conditions in global financial markets.

Initially, the cost of issuing a bond was expected to exceed that of previous RB loans. However, in order to maintain efforts to attract foreign issuers and stimulate demand from Russian banks, the Bank of Russia set a risk factor for banks' investments in RB sovereign debts equal to $100 \%$, unlike the $150 \%$ previously required in accordance with the Instruction On Statuary Ratios of Banks (according to "Basel-II"). As a result, it was able to reduce the cost of borrowing from the expected $12-14 \%$ to $8 \%$. On one hand, this was a step towards a foreign issuer on the part of Russian regulators of financial market and, on the other hand, it has led to one of the banks organizing the placement of RB government bonds withdrawing from participation in the banking syndicate, i.e., Vnesheconombank was dissatisfied with the interest rates on bonds.

Sberbank was the leading bank involved in the placement of bonds. This gave an additional guarantee of successful placement, as Sberbank has the necessary liquidity and opportunities to support the market. The banking syndicate also included Gazprombank and Al'fa Bank.

The investors' interest could be explained with the fact that, at the $\mathrm{RB}$ investment rating of $\mathrm{B}+$ at the time (which corresponds to the assessment of capability to perform debt obligations on time and in full according to the classification of the international rating agency Standard and Poor's Corporation), its sovereign bonds were placed with a significant premium compared to bonds of subjects of the Russian Federation at similar levels of risk that had the opportunity to borrow at a rate of slightly less than $8 \%$ on the stock market. The $\mathrm{RB}$ bonded debt cost included premiums for country risk and for the first entry on the Russian stock market.

In the first year of circulation in the Russian MICEX Stock Exchange, the market of RB sovereign bonds was low liquid and had a small volume of daily operations. This was connected primarily with the fact that Belarus, 01 are securities not for short-term investments that can be sold quickly; and secondly, 
Table 4. Comparative analysis of international stock markets for placement of RB sovereign bonds*

\begin{tabular}{|c|c|c|}
\hline Stock market & Advantages & Disadvantages \\
\hline $\begin{array}{l}\text { The Russian } \\
\text { Federation }\end{array}$ & $\begin{array}{l}\text { 1. The issuer is known by potential investors } \\
\text { owing to the world trade; it arouses the inves- } \\
\text { tors' trust. } \\
\text { 2. There is successful experience of attraction } \\
\text { of debt funds on the stock market. } \\
\text { 3. Regulatory bodies on financial markets are } \\
\text { interested in attraction of foreign issuers. }\end{array}$ & 1. The risk of one creditor. \\
\hline The EC & $\begin{array}{l}\text { 1. Creation of image of a firm borrower in the } \\
\text { world financial market.2. Diversification of the } \\
\text { risk of one creditor. }\end{array}$ & $\begin{array}{l}\text { 1. Distrust of investors to issuers from developing coun- } \\
\text { tries; it has an effect on the risks of partial placement, low } \\
\text { liquidity, and disinvestment in case of change of conditions. } \\
\text { 2. Overestimation of country and political risks; it has an } \\
\text { effect on higher interest rates. } \\
\text { 3. Unfavorable situation at the EC financial market itself. }\end{array}$ \\
\hline China & 1. Entry the Asian stock markets. & $\begin{array}{l}\text { 1. The issuer is little known by potential investors; it can } \\
\text { cause to higher interest rates. } \\
\text { 2. Complexity of regulation of the stock market in inland } \\
\text { China; it can cause additional problems with the proce- } \\
\text { dures of emission and listing and narrow the range of } \\
\text { potential investors. } \\
\text { 3. Selection of borrowing currency and conducting policy } \\
\text { of artificial lowering of Chinese yuan rate. }\end{array}$ \\
\hline
\end{tabular}

* The authors' own work.

many investors assessed the RB credit risk higher than the interest rates on the issued bonds.

In the second half of 2011, the yield on the bonds of Belarus, 01 on the secondary market increased to 20-25\%. Trading on the MICEX Stock Exchange become more active due to the fact that, against a background of the observed increase in yields on sovereign debts of European countries, some of which were actually on the border of default, the risk of RB default was not so great. Many banks, which had RB bonds on balance, began to sell them because of the deterioration of their own stability indexes, without the possibility of holding speculative securities, while the demand did not have time to react and the bonds were forcedly sold at a substantial discount. Investors also appreciated the fact that the main trading partner of the Republic of Belarus is Russia; thus, the state will not allow defaults on its sovereign ruble bonds.

On this basis, we can mark several peculiarities of the debut placement of RB sovereign bonds on the Russian market:

- unique access to the market ( $\mathrm{RB}$ is the first foreign state) issuer (not an international financial institution), which yielded the right to the public placement of government bonds and their circulation in the Russian Federation in accordance with the RF legislation requirements;

- a specific purpose of the placement of sovereign bond, i.e., the payment of syndicated bridge $\operatorname{loan}^{2}$ of Russian banks provided to the Government of Belarus on December 31, 2009 for a period of 13 months at a rate of 6 bln Russian rubles;

—successful placement, i.e., the issuer has attracted funds in full at a relatively low rate and has fulfilled all obligations to investors on time.

Taking into account the placement of RB sovereign bonds, the selection of an optimal market for subsequent placements has become one of the major problems in the field of RB public debt management. It seems that the main attention should be given to the stock markets of Russia, the EU, and China, which have positive and negative aspects for the Republic of Belarus presented in Table 4.

A comparative analysis of the stock markets of Russia, the EU, and China in terms of possible advantages for placing RB sovereign bonds shows that, at the present stage, the stock market of Russia is most preferable, as it most closely resembles the conditions of the Republic of Belarus and is sufficiently liquid. At the same time, the EU stock market provides the maintenance of publicity status and the formation of an appropriate image, while the Chinese market is interesting from the standpoint of the development of a new direction and the diversification of risk.

We see prospects for placeming RB sovereign bonds in the following areas:

- further issuance of sovereign bonds with due account for their diversification, i.e., attaining the

\footnotetext{
${ }^{2}$ Bridge loan-so called intermediate loan, i.e. short-term loan for the reconciliation of urgent financial problem.
} 
optimum ratio of RB debt obligations by yield, maturity, etc.;

- maintaining gross external debt at an economically safe level;

- enhancing $\mathrm{RB}$ credit rating in order to reduce the government bond yields ${ }^{3}$;

-ensuring strict compliance with RB financial obligations to creditors in order to create the image of a firm borrower in the financial market;

- developing appropriate infrastructure of the government bonds market, ensuring its transparency, and solving problems of unifying RB legislation and Russian legislation and international conditions for securities trading, which were set as early as in 2002 [5].

Possible difficulties with placing RB sovereign bonds can be successfully overcome both at the level of nationwide management in the framework of the implemented program of socio-economic development of the Republic of Belarus [6] and the programs of development of securities market [7] and in the course of acquiring experience in the placement of government securities in the financial markets of foreign countries.

Moreover, as early as in 2011 , the problem was posed of bringing RB corporate borrowers to the international financial market, including the Russian market, which is considered to be highly liquid. In this regard, in 2014-2015, it is assumed that IPO 4 of the largest Belarusian companies, RUP MTZ, RUP Gomsel'mash, OAO Gorizont, and OAO BATE, will be carried out [8].

These measures for the active placement of RB sovereign bonds in international financial markets will promote the attraction of additional sources of financing expenditures of the government budget and refinancing RB public debt, as well as the development of the securities market as a whole. Ultimately, we see a mutual benefit from the cooperation between the Republic of Belarus and the Russian Federation in this

${ }^{3} \mathrm{RB}$ rating was determined as $\hat{\mathrm{A}} 1$ (Moody's) $/ \hat{\mathrm{A}}+(\mathrm{S} \& \mathrm{P})$ at the moment of the debut placement of Eurobonds.

${ }^{4}$ IPO is an initial public offering, the first public placement of shares on a stock exchange. field in a more efficient solution of the state problem related to the wide use of financial tools recognized by the world community and the successful integration of states into the global financial system.

\section{REFERENCES}

1. The Structure of the Belarus External Debt by Types of Financial Instruments, in The Balance of Payments of the Republic of Belarus over 2011 year, (NB RB, Minsk) [in Russian].

2. Normative Documents Regulating the Government Securities Market. http://www.minfin.gov.by/rmenu/ equity-market/acts/securities/. Cited November 13, 2012.

3. The Republic of Belarus has paid back the Syndicated Loan of the Russian Banks in the Amount of Six Billion Russian Rubles by Means of Placement of Bonds on Russian Market. http://www.primetass.by/News/show.asp?id=88293. Cited November 14, 2012.

4. Disclosure of Information. http://www.minfin.gov.by/rmenu/dolg/vnesh_dolg/invest/raskinfo/. Cited November 15, 2012.

5. The RB Council of Ministers Resolution issued on November 30, 2002, No. 1663. Sistema Konsul'tantPlyus.

6. Decree of the President of the Republic of Belarus issued on April 11, 2011 "On Approval of the Program of Socio-Economic Development of the Republic of Belarus for 2011-2015". No. 136. Sistema Konsul'tantPlyus. Cited November 18, 2012.

7. The RB Council of Ministers Resolution issued on April 12, 2011 "On the Program of Development of the securities market in the Republic of Belarus for 20112015”. No. 482/10. Sistema Konsul'tantPlyus. Cited November 18, 2012.

8. In 2014-2015 It is Planned to Carry out IPO of Five Giant Belarusian Industrial Companies. http:// news.tut.by/economics/320204.html. Cited November 13, 2012.

Samokhovets, Mariya Pavlovna, Cand. Sci. (Econ.), assistant professor

Kravtsova, Natal'ya Igorevna, Cand. Sci. (Econ.), senior lecturer Translated by E. Bataeva

SPELL: 1. unplaced 


\section{Contents}

Studies on Russian Economic Development

Vol. 25, No. 3, 2014

A simultaneous English language translation of this journal is available from Pleiades Publishing, Ltd.

Distributed worldwide by Springer. Studies on Russian Economic Development ISSN 10757007.

\section{Macroeconomic Problems}

Approaches to Measuring the Dynamics and Structure of Human Capital and Assessing its Accumulated Impact on Economic Growth

A. V. Suvorov, N. V. Suvorov, V. G. Grebennikov, V. N. Ivanov, O. N. Boldov, M. D. Krasil'nikova, and N. V. Bondarenko p. 215 abstract

Input-Output Macroeconomic Model as the Core of Complex Forecasting Calculations

\section{A. A. Shirov and A. A. Yantovsky p. $225 \underline{\text { abstract }}$}

Changing Balance Between Private and Public Sectors in the Russian Big Business in 2000-2013: the Subjective Approach

Ya. S. Pappe and N. S. Antonenko p. 235 abstract

\section{Industries and Interindustry Complexes}

Evaluation of Strategic Threats in Predictive Studies of Power Industry

Yu. D. Kononov p. 246 abstract

System for Scenario Planning and Forecasting World Prices for Steel and Metallurgical Raw Materials

A. G. Malanichev p. 251 abstract

\section{Financial Problems}

Features and Competition in the Market for Mortgage Insurance in the Russian Federation A. A. Tsyganov, D. V. Bryzgalov, and A. D. Yazykov p. 259 abstract 


\section{Labor and Employment}

Construction of Balance of Territorial Mobility of Employed Population:

Case Study of Federal Districts of the Russian Federation

E. A. Edinak and A. G. Korovkin p. 265 abstract

\section{Economy and Ecology}

Ecological Restrictions of Modern Economic Growth

\section{A. Kirshin p. 276 abstract}

\section{Regional Problems}

Analysis of Tendencies in Regional and Sectoral Structure of Economy of Subjects of the Russian Federation

T. G. Dubynina and V. A. Malakhov p.283 abstract

\section{Economy of Cis Countries}

Prospects for Attracting Financial Resources in International Markets by the Republic of Belarus

M. P. Samokhovets and N. I. Kravtsova p. 291 abstract

\section{Economy and Enterprises}

Russian Enterprises in Late 2013: Response to WTO Accession and Slowing Down of the Economy

D. B. Kuvalin and A. K. Moiseev p. 296 abstract

\section{Demography}

Forecasting Second Births among Russian Women: Sociological and Statistical Approaches

O. M. Shubat and A. P. Bagirova p.312 abstract

Pleiades Publishing home page $\mid$ journal home page $\mid$ top

If you have any problems with this server, contact webmaster. 